\title{
Северный «номадизм»: мобильность этнических групп коренного и некоренного населения в практиках пространственного освоения Сибири (на примере Сургутского района XMAO - Югры)
}

\author{
Елена А. Ерохина \\ Институт философии права Сибирского отделения Российской академии наук; \\ Новосибирский национальный исследовательский государственный университет, \\ Российская Федерация
}

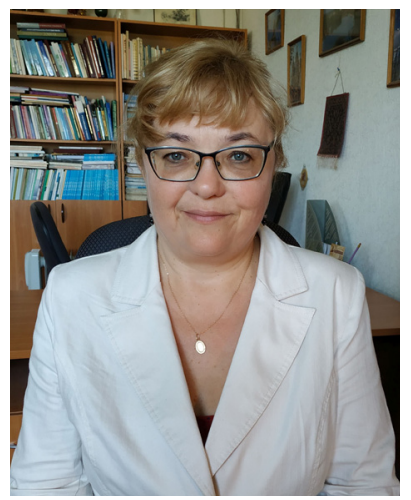

В статье анализируется роль различных социальных институтов в пространственном развитии Обского Севера. На примере Сургутского района Ханты-Мансийского автономного округа (Югры) показано влияние государственного регулирования и самоорганизации общества на формирование пространственного каркаса расселения. Исследуются поселенческая структура и транспортная инфраструктура Сургутского района как результат взаимного наложения старожильческой, советской и постсоветской моделей освоения пространства.

Раскрываются функции неформальных социальных институтов (родства, свойства, землячества) в пространственном развитии Севера. Выявлено их значение для воспроизводства населения на Севере из числа как коренных малочисленных народов (КМНС) Югры, так и представителей некоренных для Обского Севера этносов. Отмечено, что этнические сети, фундированные в неформальных институтах, выступают самостоятельными инструментами пространственной мобилизации. Их работа облегчает трудности миграции и адаптирует к «новой жизни» в местах укоренения нескольких поколений мигрантов. Дается представление о «номадном» характере не только автохтонных народов Севера (хантов, манси, ненцев), но и иных этнических групп, представленных в структуре межэтнических сообществ Обского Севера.

Эмпирическую базу исследования составили интервью с жителями Сургутского района Ханты-Мансийского автономного округа (ХМАО) и Тазовского района Ямало-Ненецкого автономного округа (ЯНАО): славянами, представителями народов Поволжья, Кавказа и Средней Азии, этнических групп КМНС (всего более 40 интервью). Кроме материалов экспедищии 2018 г. в основу статьи легли результаты предыдущих полевых исследований, осуществленных автором в 1994, 2013 и 2014 г2.

Ключевые слова: пространство; пространственное освоение; Сибирь; Север; Югра; мобильность; этнические сети; родство; землячество; номадизм; северный номадизм

"Работа выполнена по программам фундаментальных научных исследований, определяемых Президиумом РАН.

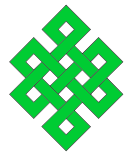

Для цитирования

Ерохина Е. А. Северный «номадизм»: мобильность этнических групп коренного и некоренного населения в практиках пространственного освоения Сибири (на примере Сургутского района ХМАО - Югры) [Электронный ресурс] // Новые исследования Тувы. 2019, № 3. URL: https://nit.tuva.asia/nit/article/view/865 (дата обращения: дд.мм.гг.). DOI: 10.25178/nit.2019.3.6

Ерохина Елена Анатольевна - доктор философских наук, доцент, ведущий научный сотрудник отдела социальных и правовых исследований Института философии и права Сибирского отделения Российской академии наук; ведущий научный сотрудник Гуманитарного института Новосибирского национального исследовательского государственного университета Адрес: 630090, Россия, г. Новосибирск, ул. Николаева, д. 8. Тел.: +7 (383) 330-22-40. Эл. адрес: leroh@ mail.ru ORCID ID: 0000-0003-1513-4557

Erokhina Elena Anatolyevna, Doctor of Philosophy, Associate Professor, Leading Research Fellow, Department of Social and Legal Studies, Institute of Philosophy and Law, Siberian Branch, Russian Academy of Sciences; Leading Research Fellow, Institute of the Humanities, Novosibirsk State University. Postal address: 8 Nikolaev Street, 630090 Novosibirsk, Russian Federation. Tel.: +7 (383) 330-22-40.E-mail: leroh@mail.ru 


\title{
'Nomadism' of the North: mobility of ethnic groups of indigenous and non-indigenous population in the practices of spatial development of Siberia (the case of Surgut raion of Yugra)"
}

\author{
Elena A. Erokhina \\ Institute of Philosophy and Law, Siberian Branch, Russian Academy of Sciences; \\ Novosibirsk State University, Russian Federation
}

The article analyzes the role of various social institutions in the spatial development of the Ob's' North. The example of the Surgut raion of the Khanty-Mansi Autonomous Region (Yugra) shows the influence of state regulation and social selforganization on shaping the spatial framework of human settlement. The settlement structure and transport infrastructure of the Surgut raion are treated in the article as a result of the mutual overlay of the "old-timer", Soviet and post-Soviet models of spatial exploration.

The article also explains several functions informal social institutions (such as kinship, affinal relationships, or fraternity) have over the spatial development of the North. They are significant for the reproduction of the population on the North, which is true both for indigenous minorities of the Yugra and for non-indigenous ethnic groups of the Ob' North. The ethnic networks established in informal institutions are noted to be functioning as independent actors of spatial mobilization. They facilitate the process of migration and help several generations of migrants adapt themselves to a 'new life' in locations they choose to settle in. The article also gives an idea of the 'nomadic' character not only of the autochthonous peoples of the North (the Khanty, Mansi, Nenets), but also other ethnic groups represented in the structure of inter-ethnic communities of the Ob's North.

The research is empirically based on the interviews with residents of the Surgut raion of the Khanty-Mansi Autonomous Region and the Taz Raion of the Yamalo-Nenets Autonomous Region: Slavs, representatives of the peoples of the Volga region, the Caucasus and Central Asia, and indigenous minorities of the Extreme North (more than 40 interviews overall).The basis of the article also formed the results of previous field studies carried out by author in 1994, 2013, and 2014.

Keywords: space; spatial development; Siberia; North; Yugra; mobility; ethnic networks; relationship; fraternity; nomadism; northern nomadism

"The article was written under the aegis of programs of fundamental research established by the Presidium of the Russian Academy of Sciences.

\author{
For citation: \\ Erokhina E. A. 'Nomadism' of the North: mobility of ethnic groups of indigenous and non-indigenous population in \\ the practices of spatial development of Siberia (the case of Surgut raion of Yugra). The New Research of Tuva. 2019, № 3
} [online] Available at: https://nit.tuva.asia/nit/article/view/865 (access date ...). DOI: 10.25178/nit.2019.3.6

\section{Введение}

Север и Арктика остаются в числе приоритетных и наиболее перспективных направлений пространственного развития России. Здесь сосредоточены центры нефте- и газодобычи, а сами северные регионы - доноры российского бюджета, являются субъектами РФ с наиболее высоким уровнем жизни населения. Опосредованная включенность в глобальные процессы через хозяйственную специализацию предопределила приоритетное развитие топливно-энергетического сектора и занятость значительной доли населения в добыче, переработке и транспортировке энергоресурсов. Привлекательность указанного сектора экономики обусловила значительную емкость рынка труда, что стало причиной постоянного притока на север, в том числе в Югру, этнически разнородного населения.

Коренным для Ханты-Мансийского автономного округа (Югры) населением являются северные автохтоны (ханты, манси, ненцы, коми) и русские старожилы Югры. По данным Всероссийской Переписи 2010 г., в структуре населения Ханты-Мансийского автономного округа (ХМАО) доля ханты составляла $1,2 \%$ (около 20 тыс. чел), манси - 0,7\% (11 тыс. чел), ненцев - 0,1\% (1,5 тыс. чел), коми и коми-пермяков по 2,5 тыс. чел., что составляет вместе 0,4\%. Таким образом, доля индигенного населения в ХМАО не превышает 2,5\% от общей численности населения. Численность славянского населения составляет более $3 / 4$ от всех жителей ХМАО (русские $-68,1 \%$, украинцы $-6,4 \%$, белорусы $-1 \%$ ). По мнению некоторых 
экспертов, старожилами в ХМАО являются также представителей народов Поволжья (башкиры - 2,5\%, чуваши $-0,9 \%$, мари $-0,5 \%)$ и татары (7,6\%), в том числе сибирские ${ }^{1}$.

Этническое многообразие вносит существенный вклад в воспроизводство экономической многоукладности Югры. Оба фактора в комплексе выступают предпосылками сохранения противоречия между региональной ориентацией на сырьевую специализацию региона в системе разделения труда и реально существующим многообразием форм собственности, экономических укладов, форм хозяйственного освоения Севера. Указанное противоречие является одной из самых существенных проблем пространственного развития Обского Севера, так как является потенциальным источником конфликтогенеза в отношениях между старожильческим населением округа (коренными народами и русскими старожилами Севера) и предприятиями ТЭК. Каждая из сторон имеет собственный опыт и свою модель освоения Севера, постольку различны их интересы как хозяйствующих субъектов, разниться их отношение к пространству, практики укорененности и мобильности.

Целью настоящей статьи является выявление роли неформальных институтов самоорганизации как структур пространственной мобильности этнически разнородного населения Югры. Родство, свойство и землячество рассматриваются в статье как самостоятельные, наряду с рынком и государством, институциональные факторы пространственного развития Севера. Этнические сети, фундированные в неформальных институтах, определены как механизмы пространственного развития, дополняющие внеинституциональные (поселенческую структуру и транспортную инфраструктуру) факторы, а также компенсирующие негативные эффекты воздействия иных (государства и рынка) институциональных факторов. Их самостоятельное значение заключается в преобразовании миграционного намерения в действие, в содействии пространственной мобилизации, в адаптирующем воздействии мигрантов в местах укоренения.

Эмпирической основой исследования стали материалы экспертных интервью, собранных автором в 2013, 2014, 2018 гг. в Ханты-Мансийском автономном округе. Последняя экспедиция 2018 г. в Сургутский район позволила собрать более 20 интервью с представителями различных профессий, разного социального статуса, возраста и уровня образования. Исследование опиралось на использование качественных методов, в том числе групповых и индивидуальных нарративных интервью с жителями г. Сургута, пос. Федоровский, с.п. Русскинская, со старожилами и местными жителями, представителями коренных малочисленных народов Севера (хантами), народов Поволжья (чувашами и татарами), Кавказа (ногайцами, ингушами, азербайджанцами), Средней Азии (таджиками и киргизами), славянских этносов (русскими и украинцами) Более 15 интервью по проблеме соотношения укорененности и мобильности на Обском Севере, выявлению основных типов связи населения Севера с его обитаемым пространством удалось собрать в Тазовском районе Ямало-Ненецкого автономного округа (ЯНАО). Материалы этих интервью, которые публикуются впервые ${ }^{2}$, также послужили раскрытию темы.

\section{Человеческое развитие как ориентир пространственного освоения Севера}

Разделение на вестернизированные центры и консервативную провинцию остается в настоящее время одной из фундаментальных детерминант дезинтеграции российского общества и серьезным вызовом его будущему. Данное обстоятельство актуализировало необходимость осмысления рисков пространственного развития, порожденных противоречивыми тенденциями модернизации и архаизации социального пространства.

Такая ситуация была осмыслена в парадигме «новой экономической географии», которая, наряду с особой ролью эффектов пространственной концентрации и транспортных коридоров самое пристальное внимание уделяет значению институциональных факторов. Наличие или отсутствие институциональных барьеров и ограничений способно облегчать или усложнять работу социальных лифтов, разгонять или тормозить рост человеческого капитала, ускорять или замедлять пространственное развитие. Как полагает Н. В. Зубаревич, качественное улучшение характеристик обитаемого пространства способно производить кумулятивные эффекты: концентрация ресурсов в центрах развития формирует среду

\footnotetext{
${ }^{1}$ Сводные итоги Всероссийской переписи населения 2010 года. Т. 4. Национальный состав и владение языками, гражданство. Табл. 4. Население по национальности и владению русским языком по субъектам Российской Федерации (2010) [Электронный ресурс] // Федеральная служба государственной статистики РФ. URL: http://www.gks.ru/free_doc/new_site/perepis2010/croc/ perepis_itogi1612.htm (дата обращения: 16.05.2019).

${ }^{2}$ Некоторые материалы полевых дневников были опубликованы в статье: Ерохина, 2019. Исследования 2018 г. проводились в рамках Интеграционного проекта СО РАН. Ранние исследования осуществлялись в рамках других проектов.
} 
для инноваций, трансформирующих сам центр, а затем, по закону диффузии, инновации транслируются на периферию, хотя и с временным лагом (Зубаревич, 2014: 8). Поскольку главным ресурсом экономики является человек, то ключевым для понимания пространственного развития оказывается концепт человеческого развития, связывающий компетенции людей, с одной стороны, и институциональные возможности, с другой стороны, с перспективой инновационного развития территорий, по привычке относимых к периферии.

13 февраля 2019 г. Правительство РФ утвердило Стратегию пространственного развития РФ до 2025 г. (Об утверждении Стратегии ... , 2019: Электр. ресурс). Стратегия предполагает формирование опорных зон в Арктике, направленных на развитие Северного морского пути как перспективного транспортного коридора из Европы в Азию. Такие планы требуют серьезного научного обоснования. В XXI веке государство вновь, как в былые времена, намерено прибегнуть к элементам административного управления и планового регулирования, без которого невозможна концентрация и мобилизация материальных, людских и денежных ресурсов. Однако, как отмечает В. А. Крюков, освоение пространства заключается не только в строительстве коммуникаций и городов (Крюков, 2019: 4).

Исследование пространственного развития Севера поставило ряд новых вопросов, в том числе проблему соотношения его институциональных и внеинституциональных факторов, роли государства и неформальных институтов в освоении Севера, связи между треками пространственного перемещения людей и индивидуальными траекториями их жизненного пути. Если предположить, что социальный институт есть результат коллективного воображения социального порядка, то этнические сети, фундированные в неформальных институтах, оказываются элементами инфраструктуры пространственного перемещения.

В тексте Стратегии пространственное развитие определяется как совершенствование системы расселения и территориальной организации экономики, в том числе за счет проведения эффективной государственной политики регионального развития. В документе Ханты-Мансийский АО объединен с Ямало-Ненецким АО и Тюменской областью в Западно-Сибирский макрорегион, территорию, совпадающую с ранее существующими границами Тюменской области, включавшей в советский период ХМАО и ЯНАО (Об утверждении Стратегии ..., 2019: Электр. ресурс). Таким образом, определение специфики человеческого развития Югры с учетом комплекса институциональных и внеинституциональных характеристик социальной инфраструктуры моногородов, экономики недропользования и традиционного образа жизни сельского населения Обского Севера оказывается актуальной научной проблемой. В качестве одного из ее аспектов в статье рассматриваются факторы пространственной мобильности на Севере как условия воспроизводства его населения.

Стратегия в качестве отраслей перспективной эффективной экономической специализации определила для Югры добычу полезных ископаемых (1), производство кокса и нефтепродуктов (3), лесоводство и лесозаготовку (4), рыболовство и рыбоводство (5) ${ }^{1}$. В то же время в качестве неэффективной, но критически важной для развития региона отрасли, Стратегия выделила растениеводство и животноводство (там же). Отмеченное в тексте Стратегии противоречие между сырьевой моноспециализацией и необходимостью развития сельскохозяйственного кластера Югры проявляется, в частности, в столкновении интересов предприятий топливно-энергетического комплекса и общин коренных малочисленных народов Севера (КМНC) региона (Ерохина, 2018: 83). Традиционный образ жизни требует активной хозяйственной деятельности вне поселений, на угодьях и стойбищах, доступ к которым нередко перекрыт контрольно-пропускными пунктами недропользователей. Одновременно с ограничением мобильности усиливается экологическая нагрузка на среду традиционного природопользования коренного населения Югры, что, без сомнения, сужает возможности для ведения традиционного хозяйства.

Существенный вклад в изучение этнокультурных механизмов сохранения традиционного образа жизни и традиционных знаний КМНС региона на современном этапе внесли этнографы и антропологи, в том числе И. В. Абрамов, О. Э. Балалаева, А. В. Головнев, Ю. Н. Квашнин, Н. И. Новикова и др. (Квашнин, 2012; Головнев и др., 2014; Балалаева, 2014; Новикова, 2016; Абрамов, 2017). Мониторинг этносоциальных процессов воспроизводства человеческого потенциала национально-смешанных поселений Югры в постсоветский период проводился В. В. Мархининым, И. В. Удаловой, Г. А. Выдриной, Е. А. Тюгашевым, Ю. В. Попковым (Мархинин, Удалова, 2002; Тюгашев, Выдрина, Попков, 2004). Процессы естественного расселения и экономической самоорганизации, фундированные в неформальных институтах, имеющих иную, нежели рынок или государство, природу, были исследованы социологами,

\footnotetext{
${ }^{1}$ Указанная в скобках цифра обозначает ранг приоритетного направления развития.
} 
экономистами, географами М. Г. Агаповым, Н. Ю. Замятиной, Ю. М. Плюсниным, И. Е. Штейнберга, В. П. Клюевой, Л. Я. Рахмановой и др. (Штейнберг, 2009; Рахманова, 2018; Замятина, Пилясов, 2018; Плюснин, 2018; Агапов, Клюева, 2018).

Эти работы открыли перспективу изучения мобильности этнически разнородного населения Югры в двух проекциях: как результат пространственного перемещения и движения по сетям родства, свойства или землячества представителей разных этносов, выходцев из различных регионов России и сопредельных стран, некогда бывших частью СССР.

\section{Дороги и марируты Югры}

До начала XX века поселенческая структура Югры формировалась на основе естественного расселения. Время от времени государство то стимулировало, то тормозило приток населения. Главными транспортными коридорами оставались бассейны крупных сибирских рек (Обь, Иртыш, Таз, Пур), а также их притоков. Естественной границей, разделяющие историко-культурные области Югры и более северной, арктической зоны, является граница тайги и тундры. На территории современного XMAO, в таежной зоне, русские старожильческие поселения формировались в XVII-XIX вв. и располагались преимущественно по берегам Оби: Сургут, Сытомино, Локосово, Тундрино. На территории современного ЯНАО, в зоне тундры, русских поселений, за исключением торговых факторий, не было (Ерохина, 2019: 158).

Автохтонное население крупных поселений в регионе не основывало: каждый род был связан со своей территорией, от которой получал все необходимое для оленеводства, охоты, рыболовства и собирательства. В 1930-1940-х гг. советская власть провозгласила курс на переход к оседлому образу жизни и в бассейнах рек - притоков Оби (Пима, Большого и Малого Югана, Агана, Тромъёгана) - появились национальные деревни. Строительство национальных, и не только, поселков осуществлялось в значительной мере усилиями спецпереселенцев. В целом весь указанный период характеризуется переходом к принудительным мерам расселения и закрепления населения на территории, к использованию труда заключенных и спецпереселенцев в строительстве, рыбозаготовке, сельском хозяйстве (Скипина, Чекрыгина, 2015: 33-37). Тогда же окончательно изменилось соотношение автохтонного и пришлого населения в пользу мигрантов, прежде всего славян (Ерохина, 2019: 159).

В 1950-1960-е гг. происходит отказ от принудительных методов прикрепления населения. В период «оттепели» власть ищет мотивационные стимулы для воспроизводства населения на Севере. В рамках плановой экономики поиск завершается становлением топливно-сырьевой специализации региона на рубеже 1960-х и 1970-х гг. С этого времени началось активное промышленное освоение Обского Севера. Высокие зарплаты, романтика вызова и покорения пространства, общественный подъем, вызванный достижениями СССР в освоении космоса, в развитии науки, техники и технологий, мобилизовали на освоение Севера население многих областей СССР, в том числе из регионов с традиционно высоким уровнем нефте- и газодобычи: с Кавказа и Поволжья. Это обусловило рост в структуре населения ХMАО и ЯНАО азербайджанцев, татар, башкир, чувашей, представителей народов Дагестана (там же).

Тогда же возникает новая транспортная инфраструктура. Строительство железнодорожной дороги от Тюмени до Уренгоя (1966-1988 гг.) связало Север с Уралом и Южной Сибирью. Развитие сети автодорожного транспорта облегчило доступ ко многим населенным пунктам. В этот период усилия государства по мобилизации населения были направлены на индустриальное освоение ресурсных богатств Севера. В настоящее время не только пространственный каркас расселения, но и качество транспортной инфраструктуры, связывающей поселения Сургутского района ХМАО в единую сеть, зависят от вклада добывающих компаний, основных хозяйствующих субъектов в районе: «Сургутнефтегаза», «Лукойла», «Газпрома».

Таким образом, на географической карте Сургутского района можно найти следы трех моделей пространственного освоения. Первая модель, связанная с естественным расселением по берегам больших рек, репрезентирует практики русских старожилов. Вторая модель порождена принудительными практиками прикрепления к пространству, которые использовало советское государство в 1930-1950 гг. Третья модель отражает плановый подход к промышленному освоению Севера, для которого характерны активная роль государства в индустриализации, ориентация на индивидуальную мотивацию и героический пафос преодоления.

Наложение повседневных практик пространственного перемещения между поселениями на географическую карту Сургутского района позволило сделать допущение о радиально-концентрическом характер его пространственной структуры. Элементами последней являются: 1) «большой» центр - Сургут; 
2) расходящаяся по направлению от центра к периферии сеть автодорог; 3) три кольца периферии внутреннее (Снежный, Черный мыс и другие «спальные районы» Сургута, некогда бывшие самостоятельными поселениями), внешнее (пригородные поселки Белый Яр, Барсово, Солнечный) и «малые» центры (Лянтор, Федоровский, Нижнесортымский, Когалым, Лангепас); 4) «малые» центры окружены сетями радиально расходящихся дорог, ведущих по направлению к промышленным объектам; 5) сельские населенные пункты, часть из которых являются старожильческими (Локосово, Лямина, Угут и др.), тогда как другая часть представлена национальными и национально-смешанными поселениями (Русскинская, Тром-Аган и др.).

Две системы транспортного сообщения, старая - речная, и новая, сформированная в советский период, должны, казалось бы, облегчить транспортную доступность в самые отдаленные места. На практике же речная транспортная сеть деградирует. Вместе с ней приходит в упадок старожильческая культура русских поселений на берегах Оби: Тундрина, Сытомина, Локосова. С ликвидацией ЗападноСибирского речного пароходства в 2017 г. доступ туда по воде оказался затруднен. Сеть автомобильного пассажирского сообщения переживает период трансформации после того, как в 2018 г. произошла реорганизация пассажирских автоперевозок. Обслуживание их маршрутов, а также содержание автостанций Сургутского транспортного узла стало бизнесом частных коммерческих компаний.

Вместе с тем строящаяся автодорога, Северный широтный коридор, уже позволила связать с Сургутом и «большой землей» некоторые «медвежьи» в недавнем прошлом «углы». В будущем эта магистраль соединит Пермский край на западе с Томской областью на востоке.

Мобильность коренного и пришлого населения Югры задается ритмом производственной активности. Для автохтонов, индигенного населения и русских старожилов, она детерминирована сезонным циклом, включенностью в традиционные промыслы и логикой отходничества. Для некоренного населения, работающего на предприятиях ТЭК, это, конечно, график мобилизации. Для предпринимателей ритм пространственной мобильности причинно обусловлен бизнес-конъюнктурой. Так или иначе, всякая мобильность на Севере есть результат трудовой деятельности людей. Работа - это то, что дает смысл жизни на Севере, вне зависимости от рода занятий и характера труда.

\section{Люди на Севере: траектории жизненного пути}

Несмотря на неравномерность развития транспортной сети, практически все поселения Сургутского района являются открытыми для миграционного притока и по факту многонациональны. Наиболее привлекательными для миграции оказываются города и рабочие поселки городского типа. С распадом СССР и разрушением элементов плановой экономики особые ожидания возлагались на рыночные институты. Парадоксально, однако, что не только они, но и архаичные институты, такие как родство, свойство и землячество, послужили фундаментом постсоветского режима пространственного развития и воспроизводства населения Обского Севера. Примечательно, что работа данных институтов обусловливает современную динамику этнического многообразия, характерными чертами которой остаются увеличение доли выходцев с Кавказа и Средней Азии, в том числе в младших возрастных когортах, за счет расширенного воспроизводства ${ }^{1}$.

Неожиданным стало обнаружение роли неформальных институтов в рассказах респондентов из числа представителей славянских этносов. Нет ничего удивительного в том, что сильные родовые и земляческие структуры сохраняют свое влияние на обычаи и традиции, ценностные ориентиры и поведение северных автохтонов, хантов и ненцев, представителей диаспор Кавказа и Средней Азии, азербайджанцев и ногайцев. Примечательно то обстоятельство, что представители более урбанизированных этносов, например, русские, украинцы и татары, также отмечали свою включенность в миграционные потоки, движущиеся на Север в постсоветский период, в перемещение по сети родства и землячества. Такой «северный номадизм», отражающий вовлеченность представителей славянских, тюркских и иных этносов, выходцев из центральных и приволжских, сибирских и южных регионов России, в семейные, родственные и земляческие сети, показывает чрезвычайную востребованность неформальных институтов в период упадка планового хозяйства и расселения.

${ }^{1}$ Сводные итоги Всероссийской переписи населения 2010 года. Т. 4. Национальный состав и владение языками, гражданство. Табл. 4. Население по национальности и владению русским языком по субъектам Российской Федерации (2010) [Электронный ресурс] // Федеральная служба государственной статистики РФ. URL: http://www.gks.ru/free_doc/new_site/perepis2010/croc/ perepis_itogi1612.htm (дата обращения: 16.05.2019). 
Впервые такая вовлеченность неожиданно дала о себе знать в ходе полевых исследований летом 2018 г. в сельском поселении Русскинская. Здесь участники экспедиционного отряда случайно познакомились с двумя пожилыми женщинами, которых в разговоре отличал необычный акцент. В ходе бесед с одной из них удалось выяснить, что обе являются выходцами из Винницкой области Украины. Женщина пояснила, что ее пригласили земляки - односельчане, которые уже проживали в Русскинской, после того, как она овдовела и вышла на пенсию в 1992 г. Средств на жизнь было недостаточно, а на Севере ей предложили работу. Уже более 20 лет она проживает в этом национально-смешанном поселении. Хотя информант покинула Украину давно, связи с родиной она не теряет и хочет воссоединиться с детьми и внуками, которые проживают ныне в Киеве. Из беседы с ней стало известно, что в селе проживает более 15 семей из числа их односельчан. Многие имеют женатых детей и даже внуков от смешанных украинохантыйских браков. Последние в случае необходимости могут пользоваться правовым статусом КМНС.

Гипотеза о вовлеченности представителей различных этносов в движение по неформальным сетям подтвердилась в последующих интервью с русскими, украинцами, чувашами, народами Кавказа. В высказываниях участников группового интервью, которое автор статьи взяла у представителей национальных диаспор рабочего поселка городского типа Федоровский, женщина, врач, глава украинской организации, рассказала о том, как приехала на Север вслед за мужем из Луганской области. Другая женщина, представитель чувашской организации, воспитатель детского сада, также приехала из Башкирии вместе с супругом. Обе имеют взрослых детей. Их собственная профессиональная деятельность и карьера их мужей связаны с Федоровским.

Немало историй о воздействии родителей, мужей и жен, братьев и сестер, тетей и дядей, земляков на принятие решения о миграции на Север поведали нам водители такси в различных населенных пунктах на маршруте экспедиции: русские и киргизы, азербайджанцы и таджики, дагестанцы и узбеки. Так, молодой водитель 33 лет, ногаец из Дагестана, занимающийся частным извозом, в перерывах между рабочими сменами на муниципальном предприятии, рассказал о том, как приехал на Север впервые к брату после армии. Он привез своих племянников к началу учебного года. Брат уговорил его остаться. Молодой человек нашел работу, женился на русской девушке и уже более 10 лет живет на Севере. Он также рассказал, что первой из односельчан укоренилась его землячка, которую он назвал «бабой Нюрой». По его словам, она открыла магазин, после чего подтянулись другие жители кавказского села.

Еще один рассказ был записан со слов 45-летней женщины, русской, уроженки Ростовской области, жительницы поселка Тазовский ЯНАО. В начале 1990-х годов, по приглашению тетки, которая уже жила и работала на Севере, она приехала в поселок. Открытая вакансия учителя начальных классов, которую она намеревалась занять, оказалась занятой другим учителем: не удалось вовремя достать билетов на поезд. Однако, после того, как удалось устроиться в учреждение дополнительного образования, она продолжила карьеру в учреждении культуры. Здесь сложилась и ее личная жизнь, родился сын, который, после получения в Тюмени высшего образования, вернулся в поселок для того, чтобы продолжить активную трудовую жизнь на «малой» родине.

Хотя большинство информантов не планировали отъезд с Севера в среднесрочной перспективе, тем не менее, некоторые из них задумываются о том, как может сложиться их жизнь после окончания трудоспособного возраста. За исключением КМНС, представители всех этносов так или иначе рассматривают возможность переезда: либо возвращение на родину, либо переезд на юг Тюменской области, либо отъезд в Краснодарский или Ставропольский край. Даже те, кто отвергает этот вариант в будущем, такую возможность хотя бы один раз рассматривали.

Для выходцев с Кавказа и Средней Азии возвращение на родину имеет, помимо прочего, еще и экзистенциальный смысл. Многие из них хотят быть похороненными на родовом кладбище. Кладбища как места семейной памяти важны и для северных народов. Мотив семейной и родовой памяти побуждает их к восстановлению малых поселков и стойбищ на межселенных территориях, где находились или находятся их родовые угодья.

Север бросает вызов человеку. Не только суровые условия жизни, но и ошибки, допущенные самим человеком в ходе его освоения, такие, как промышленное загрязнение, оказываются испытанием. Что же выступает побудительным мотивом жизни на Север?

\section{Жизнь на Севере}

Ведущий побудительный мотив заключен в стремлении к благополучию: собственному, своей семьи, близких людей. Жизнь на Севере открывает такие перспективы. Это не только работа на предприятиях 
ТЭК, которые предлагают своим сотрудникам высокую заработную плату, социальный пакет и гарантии. Это и занятость в правоохранительных органах и социальной (здравоохранение, образование, культура) сфере, в муниципальных и дорожных службах, везде, где есть постоянная работа и социальные гарантии. Неслучайно упоминание респондентами критического срока, после которого дилемма «уехать или остаться», разрешается в пользу укоренения. Такой критический срок составляет пять лет. Проработав на предприятии пять лет, работники начинают получать ежемесячную 50\% «северную» надбавку (именно таков ее размер, по словам информантов, в ХМАО). Весь предшествующий период надбавка к их заработной плате повышается на 10\% по истечении каждого года из первых пяти лет. Достигнув максимума через пять лет, «северная» надбавка более не повышается.

Именно первые годы пребывания на Севере оказываются критическими. Нередко в первые 2-4 года принимается решение вернуться на «большую землю». Если критический период пройден, люди, как правило, остаются, даже если на словах утверждают обратное. Как отметил один из наших респондентов: «Тут все так говорят, но немногие уезжают» (Полевые материалы автора, 2018 г.).

Север с его суровыми условиями жизни и труда предъявляет высокие требования к самодисциплине. Поэтому в высказываниях респондентов в качестве другого значимого мотива отмечается престиж и общественная значимость труда, ценность трудовой этики и личной репутации, индивидуальная и коллективная ответственность за результат работы. Нередки и высказывания, в которых респонденты отмечают возможность работать на себя в таких сферах, как торгово-посредническая деятельность, предпринимательство, частный и коммерческий извоз. Высокий уровень доходов северян позволяет оставаться прибыльной сфере торговли и предоставления услуг.

Крестьянско-фермерское хозяйство не является престижной сферой труда. И без того тяжелый сельскохозяйственный труд в условиях Севера утратил экономический смысл после того, как в регион пришел сетевой ритэйл. Местный сельхозпроизводитель не может конкурировать с крупным товарным производством. Это относиться и к продукции оленеводства, рыболовства и рыбоводства, к сбору и продаже дикоросов. Развитие традиционного для коренных малочисленных народов хозяйства не дает прибыли достаточно для того, чтобы на этой основе создать крупный бизнес. Российский Север не является исключением. Без поддержки государства традиционное хозяйство оказывается в кризисе, а вместе с ним забываются родной язык и родная культура, предаются забвению традиционные знания.

Миграционная привлекательность обеспечивает приток рабочей силы в сферы, связанные с предпринимательством, торговлей и извозом, оказанием услуг различного рода. Эту нишу занимают, как правило, выходцы с Кавказа и Средней Азии, причем кавказцы предоставляют работу как своим землякам и родственникам, так и представителям других национальностей. В тоже время выходцы с Кавказа востребованы на предприятиях ТЭК, в добывающих и перерабатывающих компаниях. Наряду со славянами (русскими и украинцами) и народами Поволжья (татарами, башкирами, чувашами, удмуртами), азербайджанцы и дагестанцы являются самыми крупными этническими диаспорами региона. Работа на предприятиях ТЭК является престижной и многие из них стремятся стать членами трудовых коллективов промышленных предприятий. Однако, как утверждают респонденты, существуют неформальные карьерные ограничения для выходцев с Кавказа и Средней Азии при приеме на работу и продвижении по службе в добывающих компаниях. Существуют они и в правоохранительных органах.

В интервью упоминалась и практика карьерных преференций по родственному принципу, независимо от национальности, для работников предприятий ТЭК. Например, предприятие может выделить стипендию или направить по целевому набору на обучение в вуз ребенка своего сотрудника. Также ему может быть отдано предпочтение при приеме на работу.

Особо стоит отметить высокую межэтническую брачность во всех этнических группах, упомянутых нами. В интервью, взятых у респондентов разных национальностей, нередко упоминаются члены семьи, представители иной национальности, чаще всего супруг или супруга. Это предполагает высокую степень толерантности в межличностной сфере. В то же время есть смысл упомянуть и о межэтнической конкуренции в экономической и деловой сфере. Она в округе, по мнению респондентов, также высока и остра в отношениях между отдельными группами диаспор. В тоже время в округе есть этнические группы, весьма многочисленные, хотя и не составляющие большинство, которые играют роль посредников между доминирующим славянским большинством и выходцами с Кавказа и Средней Азии, приверженцами ислама. Это народы Поволжья, большинство из которых в округе составляют татары и башкиры. Они воспринимаются югорчанами как часть регионального межэтнического сообщества. 


\section{Заключение}

Существуют определенные социально-типические различия в мобильности автохтонов и выходцев с «материка». Для первых она неразрывно связана с традиционным укладом и родовой территорией, с сакральными местами и маршрутами перекочевок. Осознание того, что родина одна и двух быть не может, сочетается парадоксальным образом с представлением о том, что она везде, где есть олень, либо вода (река или озеро), либо еще что-то, что порождает самобытный хозяйственный уклад. Для вторых - это прагматизм и высокая ценность труда, а также возможность иметь две и даже три малых родины: откуда приехал, здесь и там, где планируется остаток жизни.

Вместе с тем есть и то общее, что сближает представителей полиэтничного сообщества Югры, и роднит их друг с другом, а также с другими северянами. Это ответственность за то, в каком состоянии ныне живущие поколения оставят природу своим наследникам. Природа Севера уникальна и хрупка. Она с большим трудом восстанавливает ресурсы своего биоразнообразия, тяжело залечивает раны, нанесенные небрежной хозяйственной деятельностью. Также хрупка и человеческая жизнь. В интерьере бесконечного пространства Севера человеческая судьба быстротечна. На Севере экзистенциальные основания человеческого бытия осознаются острее и драматичнее в силу резкой смены сезонов, суровых климатических условий, приводящих к быстрому старению организма.

Способность к коллективному действию и оказанию превентивной помощь тем, кому она необходима, является важной смысловой составляющей жизни на Севере. Однако «северный номадизм» - это еще и особая характеристика работы на Севере, что предполагает определенные личностные черты работника: индивидуальную ответственность за результат труда и самодисциплину.

И для тех, кто родился на Севере, и для тех, кто прибыл с «большой земли», жизнь на Севере является важной частью биографии. Кочевой образ жизни составляет смыслообразующую часть бытия аборигенных народов. Однако не только для них мобильность остается стержневой составляющей образа жизни. Движение составляет суть жизни на Севере, немыслимой без перемещения по огромным просторам. Это и переезд к месту работы на период мобилизации работников предприятий ТЭК, и путешествия из интерната на стойбище и обратно детей из числа КМНС во время школьных каникул, и долгожданные выезды в теплые края отпускников. Как мы и пытались показать в данной статье, это не только физические перемещения, но и результат движения по сетям неформальных институтов: родства, свойства, землячества.

\section{Благодарности}

Статья посвящается памяти доктора философских наук, профессора Василия Васильевича Мархинина. Без его советов и поддержки это исследование не могло бы состояться. Автор также выражает признательность экспертам, оказавшим помощь в проведении исследования: экс-главе сельского поселения Русскинская Александру Сытову и доценту Сургутского государственного университета Василию Мархинину.

\section{СПИСОК ЛИТЕРАТУРЫ}

Об утверждении Стратегии пространственного развития РФ до 2025 года (2019) [Электронный ресурс]// Правительство России. 14 февраля. URL: http://government.ru/docs/35733 (дата обращения: 16.05.2019).

Абрамов, И. В. (2017) Оленеводство как стратегия жизнеобеспечения манси: факторы возникновения и угасания // Вестник археологии, антропологии и этнографии. № 4 (39). С. 104-113. DOI: 10.20874/20710437-2017-39-4-104-113

Агапов, М. Г., Клюева, В. П. (2018) «Север зовет»: мотив «северное притяжение» в истории освоения Российской Арктики // Сибирские исторические исследования. № 4. С. 6-24. DOI: 10.17223/2312461X/22/1

Балалаева, О. Э. (2014) Общинное движение в Сургутском районе и община «Яун-Ях» // Северный регион: наука, образование, культура. № 1 (29). С. 35-43.

Головнев, А. В., Лёзова, С. В., Абрамов, И. В., Белоруссова, С. Ю., Бабенкова, Н. А. (2014) Этноэкспертиза на Ямале: ненецкие кочевья и газовые месторождения. Екатеринбург : Издательство АМБ. 232 с.

Ерохина, Е. А. (2018) Коренные малочисленные народы и добывающие компании на Обском Севере: сотрудничество или конфликт? // ЭКО. № 5. С. 81-92. DOI: 10.30680/ECO0131-7652-2018-5-81-92 
Ерохина, Е. А. (2019) Этнокультурные механизмы пространственного развития на Обском Севере // Пути России. Границы политики / отв. ред. М. Г. Пугачева. М. : Дело. 322 с. С. 154-162.

Замятина, Н. Ю., Пилясов, А. Н. (2018) Локальные транспортные системы в развитии Сибири и Дальнего Востока // География и природопользование Сибири. № 25. С. 93-99.

Зубаревич, Н. В. (2014) Региональное развитие и региональная политика в России // ЭКО. № 4. С. 6-27.

Квашнин, Ю. Н. (2012) Этнические и демографические процессы у тазовских ненцев в начале XXI века // Вестник археологии, антропологии и этнографии. № 3 (18). С. 141-152.

Крюков, В. А. (2019) Слабеющий скреп пространства // ЭКО. № 3. С. 4-7. DOI: 10.30680/ECO0131-76522019-4-4-7

Новикова, Н. И. (2016) Нефть, газ, коренные народы: кто напишет правила? // Вестник угроведения. № 3 (26). C. 124-137.

Мархинин, В. В., Удалова, И. В. (2002) Традиционное хозяйство народов Севера и нефтегазовый комплекс (социологические исследования в Ханты-Мансийском автономном округе). Новосибирск : Наука. $254 \mathrm{c}$.

Плюснин, Ю. М. (2018) Промыслы провинции: архаические и современные экономические практики населения // Журнал социологии и социальной антропологии. T. 21. № 1. C. 73-106. DOI: 10.31119/ jssa.2018.21.1.4

Рахманова, Л. Я. (2018) Испытание - адаптация - укоренение: осмысление и воплощение понятий на Севере и в Сибири // Пути России. 1917-2017: сто лет перемен / отв. ред. М. Г. Пугачева, В. П. Жарков. М. ; СПб. : Нестор - История. 284 с. С. 227-244.

Скипина, И. В., Чекрыгина, Е. А. (2015) Документы 1930-х гг. о спецпереселенцах на Обском Севере в фондах государственного архива Тюменской области // Вестник Костромского государственного университета им. Н. А. Некрасова. Т. 21. № 6. С. 33-37.

Тюгашев, Е. А., Выдрина, Г. А., Попков, Ю. В. (2004) Этноконфессиональные процессы в современной Югре. Новосибирск : Нонпарель. 224 с.

Штейнберг, И. Е. (2009) Процесс институционализации сетей социальной поддержки в межсемейных и дружеских обменах // Экономическая социология. Т. 10. № 2. С. 62-75.

Дата поступления: 02.06.2019 2.

\section{REFERENCES}

Ob utverzhdenii Strategii prostranstvennogo razvitiya RF do 2025 goda [On adopting the Spatial Development Strategy of the Russian Federation until 2025] (2019). Pravitel'stvo Rossii, February 14 [online] Available at: http://government.ru/docs/35733 (access date: 16.05.2019). (In Russ.).

Abramov, I. V. (2017) Olenevodstvo kak strategiya zhizneobespecheniya mansi: faktory vozniknoveniya i ugasaniya [Reindeer herding as a strategy for the life support of the Mansi: Factors of occurrence and extinction]. Vestnik arheologii, antropologii i etnografii, no. 4 (39), pp. 104-113. (In Russ.). DOI: 10.20874/2071-0437-2017-394-104-113

Agapov, M. G. and Kliueva, V. P. (2018) The North is calling!: the Northern attraction motif in the history of the Russian arctic development. Siberian Historical Research, no. 4, pp. 6-24. DOI: 10.17223/2312461X/22/1

Balalaeva, O. E. (2014) Obshchinnoe dvizhenie v Surgutskom raione i obshchina «Yaun-Yah» [Community movement in the Surgut Raion and the Yaun-Yah community]. Severnyi region: nauka, obrazovanie, kul'tura, no. 1 (29), pp. 35-43. (In Russ.).

Golovnev, A. V., Lyozova, S. V., Abramov, I. V., Belorussova, S. Yu. and Babenkova, N. A. (2014) Etnoekspertiza na Yamale: nenetskie kochev'ya i gazovye mestorozhdeniya [Ethno-expert examination on Yamal: Nenets nomad camps and gas fields]. Ekaterinburg, Izdatel'stvo AMB. 232 p. (In Russ.).

Erokhina, E. A. (2018) Korennye malochislennye narody i dobyvayushchie kompanii na Obskom Severe: sotrudnichestvo ili konflikt? [Indigenous minorities and mining companies in the Ob' north: Cooperation or conflict?]. ECO, no. 5, pp. 81-92. (In Russ.). DOI: 10.30680/ECO0131-7652-2018-5-81-92

Erokhina, E. A. (2019) Etnokul'turnye mekhanizmy prostranstvennogo razvitiya na Obskom Severe [Ethnocultural mechanisms of spatial development in the Ob' north]. In: Puti Rossii. Granicy politiki [The Ways of Russia. The Boundaries of Politics]. Moscow, Delo. 322 p. Pp. 154-162. (In Russ.). 
Zamyatina, N. Yu. and Pilyasov, A. N. (2018) Lokal'nye transportnye sistemy v razvitii Sibiri i Dal'nego Vostoka [Local transport systems in the development of Siberia and the Far East]. Geografiya i prirodopol'zovanie Sibiri, no. 25, pp. 93-99. (In Russ.).

Zubarevich, N. V. (2014) Regional'noe razvitie i regional'naya politika v Rossii [Regional development and regional policy in Russia]. ECO, no. 4, pp. 6-27. (In Russ.).

Kvashnin, Yu. N. (2012) Etnicheskie i demograficheskie processy u tazovskih nencev v nachale XXI veka [Ethnic and demographic processes of the Taz Nenets at the beginning of the 21st century]. Vestnik arheologii, antropologii i etnografii, no. 3 (18), pp. 141-152. (In Russ.).

Kryukov, V.A. (2019) Slabeyushchii skrep prostranstva [The weakening grip of space].ECO, no. 3, pp. 4-7. DOI: DOI: 10.30680/ECO0131-7652-2019-4-4-7

Novikova, N. I. (2016) Neft', gaz, korennye narody: kto napishet pravila? [Oil, gas, indigenous peoples: Who will write the rules?]. Vestnik ugrovedeniya, no. 3 (26), pp. 124-137. (In Russ.).

Marhinin, V. V. and Udalova, I. V. (2002) Traditsionnoe khoziaistvo narodov Severa i neftegazovyj kompleks (sociologicheskie issledovaniya $v$ Hanty-Mansijskom avtonomnom okruge [Traditional economy of indigenous peoples of the North and the oil and gas complex: sociological research in the Khanty-Mansi Autonomous Region]. Novosibirsk, Nauka. 254 p. (In Russ.).

Plyusnin, Yu. M. (2018) Promysly provintsii: arkhaicheskie i sovremennye ekonomicheskie praktiki naseleniya [The crafts of the province: Archaic and modern economic practices of provincial households]. Zhurnal sotsiologii i sotsial'noi antropologii, vol. 21, no. 1, pp. 73-106. (In Russ.). DOI: 10.31119/jssa.2018.21.1.4

Rakhmanova, L. Ya. (2018) Ispytanie - adaptatsia - ukorenenie: osmyslenie i voploshchenie ponyatii na Severe i v Sibiri [Testing - Adapting - Rooting: Understanding and implementation of concepts in the North and Siberia]. In: Puti Rossii. 1917-2017: sto let peremen [The ways of Russia. 1917-2017: a centenary of change]. Ed. by M. P. Pugacheva and V. P. Zharkov. Moscow, St. Petersburg, Nestor-History. 284 p. Pp. 227-244. (In Russ.).

Skipina, I. V. and Chekrygina, E. A. (2015) Dokumenty 1930-kh gg. o spetspereselentsakh na Obskom Severe $\mathrm{v}$ fondakh gosudarstvennogo arkhiva Tyumenskoi oblasti [Documents from 1930s on "special settlers" in the Ob' North in the collections of the state archive of Tyumen Oblast]. Vestnik Kostromskogo gosudarstvennogo universiteta, vol. 21, no. 6, pp. 33-37. (In Russ.).

Tyugashev, E. A., Vydrina, G. A. and Popkov, Yu. V. (2004) Etnokonfessional'nye processy v sovremennoj Yugre [Ethno-confessional processes in contemporary Yugra]. Novosibirsk, Nonparel'. 224 p. (In Russ.).

Shteinberg, I.E.(2009) Process institucionalizatsii setei sotsial'noi podderzhki v mezhsemeinykh i druzheskikh obmenakh [The process of institutionalizing social support networks in inter-family and friendly exchanges]. Ekonomicheskaya sotsiologia, vol. 10, no. 2, pp. 62-75. (In Russ.).

Submission date: 02.06.2019. 